\title{
Importance of allochthonous material in benthic macrofaunal community functioning in estuarine salt marshes
}

Koetsu Kon ${ }^{\mathrm{a}, *}$, Yukihiro Hoshino ${ }^{\mathrm{b}}$, Kouki Kanou, Daisuke Okazaki ${ }^{\mathrm{b}}$, Satoko Nakayama $^{\mathrm{d}}$, Hiroshi Kohno ${ }^{\mathrm{b}}$

${ }^{a}$ Department of Living Marine Resources, Atmosphere and Ocean Research Institute, The University of Tokyo, 5-1-5 Kashiwanoha, Kashiwa, Chiba 277-8564, Japan

${ }^{\mathrm{b}}$ Faculty of Marine Science, Tokyo University of Marine Science and Technology, 4-5-7 Konan, Minato, Tokyo 108-8477, Japan

${ }^{\mathrm{c} C e n t e r ~ o f ~ W a t e r ~ E n v i r o n m e n t ~ S t u d i e s, ~ I b a r a k i ~ U n i v e r s i t y, ~} 1375$ Ohu, Itako, Ibaraki 311-2402, Japan

${ }^{\mathrm{d}}$ Department of Biology, Faculty of Science, Toho University, 2-2-1 Miyama, Funabashi, Chiba 274-8510, Japan

* Corresponding author. Present address: Shimoda Marine Research Center, University of Tsukuba, 5-10-1 Shimoda, Shizuoka 415-0025, Japan.

E-mail addresses: akon@mail.ecc.u-tokyo.ac.jp, kon@kurofune.shimoda.tsukuba. ac.jp (K. Kon). 


\section{ABSTRACT}

Allochthonous input provides important food and spatial resources for estuarine benthic fauna. While it is known that autochthonous materials are important for fauna occupying small marshes, here, we present the significance of allochthonous materials for benthic fauna inhabiting a large salt marsh. To assess the effects of allochthonous input on benthic macrofaunal communities in estuarine salt marshes, we determined the source of substrate sediments and food resource utilisation patterns of benthic invertebrates in 2 temperate estuaries (the Tama River and the Obitsu River estuarine outlets into Tokyo Bay) by using stable carbon and nitrogen isotope analyses. In the Tama River estuary, which has small patches of marsh vegetation upstream of the river mouth, there was an input of sedimentary organic matter from autochthonous sources (i.e. common reed and microphytobenthos). In the Obitsu River estuary salt marsh, which is situated immediately upstream of the river mouth and is well connected to the sea, sediment consists of allochthonous sources (i.e. imported phytoplankton), along with microphytobenthos. Isotope analysis indicated that most benthic invertebrates in the Tama River estuary depend on benthic microalgae (autochthonous) as a food resource, whereas the macrofauna in the Obitsu River estuary are supported by drift macroalgae (allochthonous), in addition to microphytobenthos or phytoplankton. Our results indicated that allochthonous material provides a food resource and potential habitat for benthic macrofauna in extensive salt marshes that have a strong connection to the sea but is not substantial in smaller marshes with limited connectivity to coastal water. 
Keywords: allochthonous input, benthic fauna, estuary, food web, salt marsh, stable isotope 


\section{Introduction}

Most natural ecosystems interact with each other through the flow of nutrients and organic materials across ecosystem boundaries (Polis and Hurd, 1996; Polis and Strong, 1996). Such allochthonous resources promote secondary productivity in ecosystems that have little or no primary productivity (Polis et al., 1997). In environments with abundant primary producers, imported materials can be consumed directly by detritivores and/or after bacterial trophic mediation, and incorporated into the food web (Findlay and Tenore, 1982; Cebrian and Lartigue, 2004). Thus, allochthonous input can be a major determinant of trophic structures in many ecosystems.

Estuarine salt marshes form a common coastal ecotone that receives organic matter derived from phytoplankton, microphytobenthos, macroalgae and/or marsh and land plants (Heip et al., 1995). In these systems, benthic invertebrates (as primary consumers) are an important link between organic matter and predators. The majority of benthic invertebrates are detritivores, such as suspension and deposit feeders (Heip et al., 1995) and, in general, their food resource is particulate and sedimentary organic matter that originates from various sources. Consequently, quantifying nutritional sources is difficult when attempting to clarify the trophic structure in estuarine marsh ecosystems.

Stable carbon and nitrogen isotope analyses provide a useful tool for investigating the sources of animal nutrition. This approach is based on the following assumptions: (1) the $\delta^{13} \mathrm{C}$ values of primary producers vary because of different photosynthetic pathways or different inorganic carbon sources and (2) a consistent degree of fractionation occurs between the isotope signal of the food source and that of the 
consumer. Small or negligible $\delta^{13} \mathrm{C}$ enrichment, ranging on average between $0 \%$ and 1\%o, occurs from variations in food source (DeNiro and Epstein, 1978). For $\delta^{15} \mathrm{~N}$, a higher fractionation on average 2.6\% (Owens, 1987) to 3.4\%o (Minagawa and Wada, 1984) is usually assumed. This approach has been used to investigate the food web structure in many estuarine habitats, such as tidal mudflats (Kang et al., 2003; Al-Zaidan et al., 2006), seagrass beds ( Kneer et al., 2008; Vonk et al., 2008), mangrove forests (Bouillon et al., 2002; Kon et al., 2007) and salt marshes (Deegan and Garritt, 1997; Doi et al., 2005 Richoux and Froneman, 2007).

The foundations of salt marsh food webs have been explored, especially with respect to comparing allochthonous (imported phytoplankton and drift macroalgae) and autochthonous (in situ marsh plants and microphytobenthos) resources. Until recently, it was generally assumed that salt marsh vascular plants supported the food web via a detritus-based pathway (Teal, 1962), indicating a large contribution of autochthonous food for benthic fauna. Recent studies using stable isotope analysis, however, revealed the importance of microalgae as an important link in the food web, such as microphytobenthos and phytoplankton (Sullivan and Moncreiff, 1990; Page, 1997; Riera et al., 1999), as well as the marsh plant contribution (Currin et al., 1995; Deegan and Garritt, 1997). Consequently, the relative importance of allochthonous (i.e. imported phytoplankton and drift macroalgae) and autochthonous (i.e. in situ marsh plants and microphytobenthos) resources as nutritional sources remain unclear.

In addition, imported materials provide potential substrates for benthic fauna (i.e. the sedimentation of inorganic soil and/or mud is facilitated by the dense stems of marsh plants), with the accumulation of organic matter inducing peat formation (Li and Yang, 
2009). Benthic fauna would also benefit from such spatial resources. Furthermore, these spatial functions would be particularly evident within the vegetation of salt marshes, which consist of vegetated marshes and unvegetated mudflats. Therefore, allochthonous input may be a significant factor in providing potential habitats and food resources, although little is known about the ecological functions of allochthonous material.

Extensive loss of salt marsh and tidal mudflats from reclamation has occurred in coastal areas of Japan, particularly in Tokyo Bay, central Japan. Between 1936 and 1990, 93\% of the total intertidal area, including salt marsh and mudflats (approximately 136 $\mathrm{km}^{2}$ ), was lost (Kamatani, 1993). Currently, coastal Tokyo Bay supports only two intact marshes that differ in size and in their connectivity to adjacent coastal waters: the Tama River estuary has approximately $0.32 \mathrm{~km}^{2}$ of narrow salt marsh patches 2-6 km upstream from the river mouth, while the Obitsu River estuary supports approximately $0.45 \mathrm{~km}^{2}$ of marsh vegetation immediately upstream of the river mouth. In order to restore and/or conserve such rare marsh habitat, the function and significance of the allochthonous input should be clarified, which would, in turn, improve our understanding of these salt marsh ecosystems.

We hypothesized that allochthonous resources (imported materials, including phytoplankton and drift macroalgae) would have a greater contribution to habitat substrate and food for the benthic faunal community than autochthonous resources in the extensive marsh vegetation around the mouth of the Obitsu River estuary, whereas autochthonous resources (in situ materials from marsh plants and microphytobenthos) would have a greater contribution to the sediment and faunal food source than allochthonous resources in the relatively small marsh patches of the upper and middle 
parts of the Tama River estuary. We anticipated that such differences would be marked between habitats, with vegetated fauna being much more dependent on allochthonous resources. We therefore investigated the impacts of allochthonous input on substrate sediments as a potential habitat for benthic fauna and benthic invertebrate food resource availability, by comparing stable carbon and nitrogen isotope ratios between two estuarine marshes of different sizes and connectivity with adjacent coastal waters.

\section{Material and Methods}

\subsection{Study site}

We investigated 2 temperate estuaries at the river mouth (Tama River and Obitsu

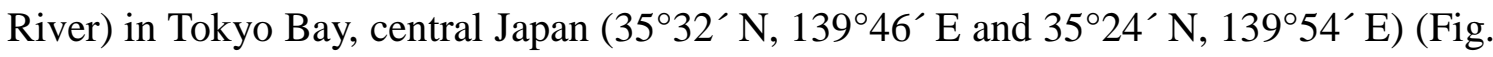
1). The Tama River estuary has approximately $0.32 \mathrm{~km}^{2}$ of salt marsh that forms long narrow bands on tidal flats that cover an area of $0.95 \mathrm{~km}^{2}$ between the river mouth and 6 km upstream. Reclamation has destroyed other marsh areas in this river, and dredging has removed much of the macroalgae that was once found around the river mouth. In contrast, the Obitsu River estuary has approximately $0.45 \mathrm{~km}^{2}$ of marsh vegetation in broad areas on the delta mudflats of the river mouth, which has an area of $12.50 \mathrm{~km}^{2}$. The mudflats support various benthic organisms, including endangered crabs, bivalves and gastropods (Furota, 1997), and the adjacent coastal area supports natural algal beds, providing drift algae as allochthonous input to the marsh. Compared to the Tama River estuary, which has marshes that are smaller and a distance from the entrance to the bay, 
the Obitsu River estuary marshes are large and have a close connection to coastal water. Both estuaries are subject to semidiurnal tides, with a tidal range of $0-2 \mathrm{~m}$. The tidal current from the bay flows into the estuary at flood tide, but freshwater inflow is significant at low tide. Both estuaries have two intertidal habitats: unvegetated open mudflats and vegetated marsh, dominated by the common reed Phragmites australis. Drift macroalgae can be found in both habitats, although only in small quantities exist in the Tama River estuary.

\subsection{Sample collection}

Sampling was carried out in the intertidal area of each estuarine marsh in July 2009. During the sampling period, salinity ranged from 0.1 to 18.8 in the Tama River estuary and from 3.0 to 29.3 in the Obitsu River estuary.

Foliage of the P. australis was collected from three different plants by hand $(n=3)$. One surface water sample was collected at high tide and phytoplankton from the sample was separated from the water in the laboratory by density fractionation in colloidal silica following the method of Hamilton et al. (2005). Surface sediment was collected by scraping the top $1-2 \mathrm{~mm}$ of substrate $(n=3)$, and microphytobenthos was extracted by making use of the phototactic movements of diatoms (Couch, 1989). However, our initial microphytobenthos samples were contaminated by unexpected materials, and so we collected the samples again in June 2010 and at the same time collected other possible primary producers, including green macroalgae (Ulva pertusa, Enteromorpha intestinalis, Enteromorpha sp., and Cladophora sp.) and red macroalgae 
(Chondracanthus tenellus, Hypnea charoides, Gracilaria vermiculophylla and Caloglossa continua) ( $n=3$ for each species, but $n=1$ for E. intestinalis in Tama River). Macroalgal species drifted randomly in the marsh habitats of both river estuaries, showing similar isotopic values. Therefore, we treated pooled macroalgae as drift macroalgae ( $n=4$ for the Tama River and $n=18$ for the Obitsu River).

Suspended solids in the surface water (300 ml) were sampled at ebb and flood tides by filtration on precombusted glass fiber filters (Whatman GF/F) ( $n=3$ for each tide), in order to collect riverine- and marine-derived particulate organic matter (POM), respectively. Surface sediment from the open mudflat and under vegetation was obtained by scraping the top 1-2 mm of substrate at low tide to collect unvegetated and vegetated sediment organic matter (SOM) samples, respectively ( $n=3$ for each habitat).

Almost all macrofaunal species were collected by excavating substrate sediment in unvegetated and vegetated habitats at low tide ( $n=3$ or 4 for each species). The sediment was washed through a 1-mm mesh sieve, and animals retained in the sieve were sorted from the debris and identified to the lowest taxonomic unit immediately. The identified species were categorised according to feeding group, as predatory carnivores, scavengers, deposit feeders and suspension feeders.

\subsection{Sample preparation and stable isotope analysis}

Common reed foliage and drift macroalgae were rinsed with distilled water. For faunal samples, the gut and intestinal system of some of the smaller species was first removed and body muscle tissue was used for the analysis; muscle tissue of larger 
species was taken directly from the chelae, abdomen, or fleshy tissues. Smaller faunal species with exoskeleton or shell, POM, and SOM samples were treated with $1 \mathrm{~N} \mathrm{HCl}$, following the method of Jacob et al. (2005), to remove possible carbonates. All samples were dried at $60{ }^{\circ} \mathrm{C}$ for at least $48 \mathrm{~h}$ and then ground to a fine powder.

Stable isotope ratios were measured on an isotope-ratio mass spectrometer (Thermo/Finnigan Delta plus XP, Hemel Hempstead, UK) and expressed as $\delta$ values relative to the conventional standards (i.e. PeeDee Belemnite for carbon and atmospheric air for nitrogen) defined as:

$$
\delta X=\left(R_{\text {sample }}-R_{\text {standard }}\right) / R_{\text {standard }} \times 10^{3},
$$

where $X={ }^{13} \mathrm{C}$ or ${ }^{15} \mathrm{~N}$ and $R={ }^{13} \mathrm{C} /{ }^{12} \mathrm{C}$ or ${ }^{15} \mathrm{~N} /{ }^{14} \mathrm{~N}$, respectively. The experimental precision (based on standard deviations of replicates of an alanine standard) was better than $0.15 \%$ for both $\delta^{13} \mathrm{C}$ and $\delta^{15} \mathrm{~N}$.

\subsection{Data analysis}

Mixing models can be used to determine the isotopic contributions of food sources in the tissues of a consumer, and thus determine the relative contributions of food sources to the consumer's diet (Phillips 2001). For $n$ isotopes, a unique solution can be calculated for up to $n+1$ sources. When this constraint is not met, as in our example in which we have 2 isotopes and 4 sources, a "most-likely" solution must be estimated. The programme IsoSource allows the possible contribution of additional sources by using an iterative approach to calculate all feasible solutions for any given number of sources and isotopic mixtures, generating a distribution of feasible solutions (Phillips 
and Gregg 2003). IsoSource was used to quantitatively estimate the contribution of each autotroph in the diet of invertebrates and in the organic matter (sedimentary and particulate). The $\delta^{13} \mathrm{C}$ and $\delta^{15} \mathrm{~N}$ values for the invertebrates and surface sediments were used as targets, while the $\delta^{13} \mathrm{C}$ and $\delta^{15} \mathrm{~N}$ values of the common reed (P. australis), microphytobenthos, phytoplankton, and drift macroalgae (all species pooled) were used as the food sources or organic origin. Before using the invertebrate values as inputs for IsoSource, they were first adjusted for trophic fractionation $\left(1.3 \%\right.$ for $\delta^{13} \mathrm{C}$ and $2.2 \%$ for $\delta^{15} \mathrm{~N}$ ) by using fractionation values from the literature (McCutchan et al. 2003). The source increment was set at $1 \%$. The tolerance was initially set at $0.1 \%$; however, if a mixture's isotopic values were out of bounds (i.e. outside the polygon delineated by the 4 food source end-members; Phillips 2001), we increased the tolerance values. These tolerances were used as buffer values when a target's isotopic ratios deviated from source ranges. Although high tolerance values may potentially decrease analytical sensitivity (i.e. by broadening the contribution range), such effects were not observed in our results (see Table 1).

The carnivorous and scavenging species were eliminated from IsoSource analysis due to an overabundance of possible food sources, including all invertebrate species. Rather, their food resources were estimated on the basis of a distance relationship in the $\delta^{13} \mathrm{C}$ and $\delta^{15} \mathrm{~N}$ scatterplot by using the trophic fractionation of the diet of invertebrates (1.3\% for $\delta^{13} \mathrm{C}$ and 3.3\%o for $\delta^{15} \mathrm{~N}$; McCutchan et al. 2003).

\section{Results}




\subsection{Stable isotope ratios in organic matter}

Stable isotope ratios differed among primary producers in both river estuaries (Fig. 2). The isotope values of organic matter were similar when considered as either suspension or sediment in the Tama River estuary (Fig. 2a). In comparison, the vegetated sediment and POM values were similar, except for unvegetated sediment, in the Obitsu River estuary. IsoSource analysis revealed the contribution of each source to the organic matter. The POM isotope values of the Tama River had the highest contribution, which was derived from drift macroalgae (allochthonous), whereas the SOM values had the highest contribution, which was derived from the common reed and microphytobenthos (autochthons) (Table 1). In situ microphytobenthos (autochthons) contributed highly to the Obitsu River's unvegetated SOM. In contrast, imported phytoplankton (allochthonous) was the greatest contributor to other organic matter, including vegetated SOM and the POM of both tides (Table 1).

\subsection{Fauna and isotope values}

In the Tama River estuary, we collected 12 species of benthic invertebrates, including 6 deposit feeders, 4 suspension feeders and 2 predatory carnivores (Fig. 2a). IsoSource estimates of each source contribution to the benthic invertebrates showed a detailed breakdown of food availabilities. Microphytobenthos contributed highly to the diets of most benthic invertebrates, including deposit and suspension feeders (Table 1). In addition to the microphytobenthos contribution, the common reed also contributed to 
the invertebrate diet in the vegetated habitat; in contrast, drift macroalgae tended to be a high contributor to the invertebrate diet in the unvegetated habitat (Table 1). Carnivorous species showed relatively similar $\delta^{13} \mathrm{C}$ and enriched $\delta^{15} \mathrm{~N}$ values compared to other in situ invertebrate species, with Macrobrachium nipponense having higher $\delta^{15} \mathrm{~N}$ values than Palaemon macrodactylus (Numbers 8 and 9 in Fig. 2a).

At the Obitsu River site, we collected 26 species comprising 13 deposit feeders, 7 suspension feeders, 3 carnivores and 3 scavengers (Fig. 2b). IsoSource analysis revealed that drift microalgae contributed to majority of their diets in the unvegetated habitat, while microphytobenthos and phytoplankton provided additional contribution in the vegetated habitat (Table 1). Four deposit feeding species, Helice tridens, Macrophthalmus japonicus, Hemigrapsus takanoi, and Assiminea japonica (Numbers 1, 3, 4 and 18 in Fig. 2), were collected in each estuary. Benthic microalgae contributed to the isotopic composition of $H$. tridens in both estuaries, although the other 3 species had different contributors between the 2 estuaries. For example, microphytobenthos was the greatest contributor in the Tama River estuary, whereas drift macroalgae was the highest contributor in the Obitsu River estuary (Table 1). Drift algae contributed to the diet of most suspension feeders (Table 1). The carnivorous and scavenging species (Numbers 7, 11 and 30-33 in Fig. 2b) had similar isotopic values to those of in situ invertebrates without the apparent enrichment of $\delta \mathrm{N}^{15}$.

\section{Discussion}

\subsection{Source of sedimentary organic matter}


Sedimentary organic matter in estuarine salt marshes can originate from various sources, including phytoplankton, microphytobenthos, macroalgae, and marsh plant detritus (Heip et al., 1995). In Japan's Nanakita River estuary, surface soil contains a large amount of organic matter derived from litter of common reed (i.e., an autochthonous resource) (Kurata et al., 2001). Our isotope results also suggest that most sediment substrate in our two sampling sites consist of autochthonous resources (marsh plants and microphytobenthos). However, the extensive vegetated habitat in the Obitsu River estuary included an allochthonous source (imported phytoplankton), suggesting that benthic habitat in this estuary also depends on allochthonous inputs as a result of its close adjacency to coastal water.

In the Tama River estuary, isotope signals from organic matter were similar as either suspension or sediment (Fig. 2a), suggesting the composition of different materials and a weak sedimentation rate from the relatively limited salt marsh vegetation patches in the estuarine portion of the Tama River. The common reed and microphytobenthos contributed to the SOM values (Table 1), indicating an autochthonous source for SOM derived from both plant sources, whether the habitat was vegetated or unvegetated. POM appears to consist of drift macroalgae (Table 1), which indicates that allochthonous material (i.e. drift macroalgae) was imported, with a minimal contribution from sediment inputs.

In contrast, the isotope values of vegetated sediment and POM were similar in the Obitsu River estuary (Fig. 2b), indicating a similar resource composition. Their highest contributor was phytoplankton (Table 1), suggesting that vegetated sediment consists of 
allochthonous resources (i.e. imported phytoplankton) that were trapped and deposited as a result of the complex structure of marsh plant stems (Li and Yang, 2009). The extensive marsh vegetation found in the Obitsu River estuary might strongly affect sedimentation rates, in addition to their sufficient connectivity with adjacent coastal water. Unvegetated sediment (Fig. 3b) was the main contributor to microphytobenthos, indicating that SOM consisted of autochthonous resources (i.e. in situ microphytobenthos), which can utilise the high light intensity of the sediment surface. Benthic microalgal biomass is likely to be much greater in open mudflats than in the shaded habitat of marsh vegetation, a finding that has been reported in other salt marsh areas (Wainright et al., 2000).

\subsection{Food resources of benthic macrofauna}

Although past studies assumed that salt marsh vascular plants supported the food web via a detritus-based pathway (Teal, 1962), recent stable isotope analyses have shown the importance of microalgae, such as microphytobenthos and phytoplankton, in the food web structure (Sullivan and Moncreiff, 1990; Page, 1997; Riera et al., 1999; Kurata et al., 2001). Our study reinforces this latter conclusion, providing further insights about the estuarine food web; in situ microphytobenthos is used as a food resource in small marshes where the connection to coastal waters is more distant (the Tama River), whereas drift macroalgae is an important factor in the food web in an estuary with more extensive marshes that are more closely connected to coastal waters (the Obitsu River). 
Microphytobenthos almost exclusively contributed to the isotopic compositions of deposit feeders in the Tama River estuary (Table 1), indicating that these guilds belong to a benthic microalgae-based food chain. Despite vegetated and unvegetated SOMs consisting of both common reed-derived detritus and microphytobenthos (Table 1), deposit feeders tend to assimilate microphytobenthos but do not assimilate the common reed. Ingestion and/or assimilation of microalgae by deposit feeders may arise through selective feeding by invertebrates. For example, some ocypodid crabs use the buccal region to selectively feed on diatoms or bacteria but do not feed in this way on vascular plant-derived detritus from surface sediments (Meziane et al., 2002). In addition, ingestion efficiency differs between common reed-derived detritus and microalgae. Fresh detritus from vascular plants tends to have large amounts of indigestible substances, such as cellulose (Lalli and Parsons, 1995), making the common reed more difficult to digest than microalgae. Therefore, invertebrates that do not have a selective feeding system, such as A. japonica or Hediste spp., will assimilate proportionately more microalgae when feeding on material consisting of both common reed-derived detritus and microalgae. Indeed, Hediste spp., which were collected from both vegetated and unvegetated habitats (29 in Fig. 2a), utilised different food sources between habitats; the former assimilate benthic microalgae and the latter assimilate freshly deposited POM derived from phytoplankton and drift macroalgae, in addition to common reed detritus (Table 1). Hence, food sources for this polychaete originate from various habitats, the results of which correspond to a previous study (Kikuchi and Wada, 1996), indicating that members of this genus are non-selective deposit feeders.

Suspension feeders of the Tama River estuary were also dependent on 
microphytobenthos, in addition to drift macroalgae, especially in the unvegetated habitat (Table 1). The resuspension of benthic microalgae or detritus is a process that increases the availability of deposited resources to suspension feeders, as reported for other intertidal ecosystems (Kang et al., 1999; Sauriau and Kang, 2000). Carnivores (including P. macrodactylus and M. nipponense) had $\delta^{13} \mathrm{C}$ and enriched $\delta^{15} \mathrm{~N}$ values that were similar to those of in situ invertebrates (Numbers 8 and 9 in Fig. 2a). This observation indicates that species in this guild utilise benthic fauna (which depend on benthic microalgae), due to nitrogen isotope fractionation following a trophic shift (McCutchan, 2003). As a consequence, in the Tama River estuary, which supports a relatively small marsh with a limited connection to coastal waters, autochthonous resources (such as benthic microalgae) supported most benthic invertebrates.

In contrast, the benthic fauna in the Obitsu River estuary utilised more allochthonous materials. Drift macroalgae exclusively contributed to the isotopic compositions of deposit feeders, especially in unvegetated habitats (Table 1), indicating that they belonged to an allochthonous resource (drift macroalgae) based food chain. For example, $M$. japonicus, $H$. takanoi and A. japonica were collected from both estuaries (Species numbers 3, 4 and 18 in Fig. 2), and their isotopic contributions for the same species differed according to the estuary (Table 1). This result strongly suggests that the major food sources of these invertebrates differed between the estuaries. Although $H$. tridens showed similar isotopic contributions in both estuaries (Table 1), the selective feeding habits of this crab species might explain the observed difference. For example, in addition to macroalgal consumption, microphytobenthos and phytoplankton contributions were also found in individuals occupying the vegetated 
habitat (Table 1). The fauna of this habitat type might utilise various sources that have been trapped and deposited as a result of the complex structure of marsh plant stems (Li and Yang, 2009). Such small-scale differences in food availability have been reported for other estuarine food webs, including salt marshes and mangrove forests (Guest et al., 2004; Kon et al., 2007). Suspension feeders appear to also utilise drift macroalgae, as indicated by IsoSource analysis (Table 1). The carnivorous and scavenging species (Numbers 8 and 9 in Fig. 2b) had similar isotopic values to those of in situ invertebrates, without the apparent enrichment of $\delta \mathrm{N}^{15}$, indicating that the species in these guilds preferentially perform omnivorous feeding. In the Obitsu River estuary, allochthonous resources, such as drift macroalgae, supported almost all benthic invertebrates, in part.

Overall, our results strongly indicate that the macrofaunal community in the Tama River estuary is supported by an autochthonous resource (in situ microphytobenthos), whereas the macrofaunal community in the Obitsu River estuary tends to utilise allochthonous inputs (drift macroalgae). Furthermore, habitat differences may also affect the structure of these 2 benthic food webs. Benthic fauna is reported to utilize marine phytoplankton at downstream locations (Sullivan and Moncreiff, 1990), whereas in situ marsh plant detritus contributes more to food resources in upstream Spartina marsh habitat due to low algal production and limited tidal mixing (Deegan and Garritt, 1997). In addition to these differences, our results suggest that marsh size and connectivity with adjacent waters could be significant determinants of allochthonous resources for benthic communities.

\subsection{Perspective for conservation of estuarine salt marshes}


Large areas of salt marsh have been destroyed by the construction of embankments in Europe, Australia and North America (Dijkema, 1987; Pethick, 2002; Kennish, 2004; Laegdsgaard, 2006). The remaining salt marshes have also been eroding rapidly, with deleterious consequences for conservation and coastal flood defense (Hughes and Paramor, 2004). Possible reasons for this erosion include coastal squeeze by increased wave and tidal action and bioturbation and herbivory by benthic invertebrates (Silliman and Bertness, 2002, 2004; Paramor and Hughes, 2004; Hughes and Paramor, 2004). In Japan, although extensive loss of salt marsh has occurred from the construction of embankments, the contributing factors to marsh erosion still need to be determined.

Recently, the use of de-embankments to recreate salt marshes has been promoted (e.g. Wolters et al. 2005), and several marsh rehabilitation programs have been carried out in Japan (Natuhara et al., 2005; Furukawa and Okada, 2006; Nakamura et al., 2006); however, most of these programs have not yet achieved their goals (e.g., Wolters et al. 2005). Several recent studies have suggested that successful marsh reconstruction requires establishing appropriate conditions, such as surface elevation, site size, soil salinity, appropriate drainage, and grazing/mowing regimes, in addition to organic input from source habitats (Crooks et al., 2002; Wolters et al. 2004). In the present study we compared two typical estuarine salt marsh food webs. The trophic structure of the Tama River estuary had a limited connection to coastal water, but the trophic structure of the Obitsu River estuary was strongly affected by coastal water and supported higher benthic faunal abundance. Such diverse macrofauna was sustained by allochthonous resources, indicating that marsh conservation of adjacent habitats must be included in 
any plan to increase or improve connectivity. Kwak and Zedler (1997) also suggested the importance of linkage among habitats in order to maintain biological diversity of salt marshes in southern California. Our results provide a contribution to rational guidelines for salt marsh conservation and/or rehabilitation; adjacent habitats are necessary to maintain diverse salt marsh food webs, in addition to maintaining the marsh per se.

\section{Acknowledgments}

The authors are grateful to $\mathrm{H}$. Kurokura (University of Tokyo) for providing valuable comments on an earlier version of this manuscript. We also thank $\mathrm{K}$. Hayashizaki (Kitasato University) and staff of the Faculty of Marine Science, Tokyo University of Marine Science and Technology, for technical support in the stable isotope analysis. K.K. was supported financially by a Research Fellowship from the Japan Society for the Promotion of Science for Young Scientists. The present work was supported by Grants-in-Aid for Scientific Research from the Ocean Policy Research Foundation, Tokyo.

\section{References}

Al-Zaidan, A.S.Y., Kennedy, H., Jones, D.A., Al-Mohanna, S.Y., 2006. Role of microbial mats in Sulaibikhat Bay (Kuwait) mudflat food webs: evidence from $\delta^{13} \mathrm{C}$ analysis. Marine Ecology Progress Series 308, 27-36. 
Bouillon, S., Koedam, N., Raman, A.V., Dehairs, F., 2002. Primary producers sustaining macro-invertebrate communities in intertidal mangrove forests. Oecologia 130, 441-448.

Cebrian, J., Lartigue, J., 2004. Patterns of herbivory and decomposition in aquatic and terrestrial ecosystems. Ecological Monographs 74, 237-259.

Couch, C.A., 1989. Carbon and nitrogen stable isotopes of meiobenthos and their food resources. Estuarine, Coastal and Shelf Science 28, 433-441.

Crooks, S., Schutten, J., Sheern, G.D., Pye, K., Davy, A.J., 2002. Drainage and elevation as factors in the restoration of salt marsh in Britain. Restoration Ecology 10, 591-602.

Currin, C.A., Newell, S.Y., Paerl, H.W., 1995. The role of standing dead spartina alterniflora and benthic microalgae in salt marsh food webs: considerations based on multiple stable isotope analysis. Marine Ecology Progress Series 121, 99-116.

Davenport, S.R., Bax, N.J., 2002. A trophic study of a marine ecosystem off southeastern Australia using stable isotopes of carbon and nitrogen. Canadian Journal of Fisheries and Aquatic Sciences 59, 514-530.

Deegan, L.A., Garritt, R.H., 1997. Evidence for spatial variability in estuarine food webs. Marine Ecology Progress Series 147, 31-47.

DeNiro, M.J., Epstein, S., 1978. Influence of diet on distribution of carbon isotopes in animals. Geochimica et Cosmochimica Acta 42, 495-506.

Dijkema, K.S., 1987. Changes in salt-marsh area in the Netherlands Wadden Sea after 1600. In: Huiskes, A.H.L., Blom, C.W.P.M., Rozema, J. (Eds.), Vegetation 
between land and sea. Dr. Junk Publishers, Dordrecht, pp. 42-49.

Doi, H., Matsumasa, M., Toya, T., Satoh, N., Mizota, C., Maki, Y., Kikuchi, E., 2005. Spatial shifts in food sources for macrozoobenthos in an estuarine ecosystem: carbon and nitrogen stable isotope analyses. Estuarine, Coastal and Shelf Science 64, 316-322.

Findlay, S., Tenore, K., 1982. Nitrogen source for a detritivore: detritus substrate versus associated microbes. Science 218, 371-373.

Furota, F., 1997. Benthos. In: Numata, S., Furota, T. (eds)., Biological report in Tokyo Bay. Tsukiji Shokan, Tokyo, pp. 45-114. (in Japanese)

Furukawa, K., Okada, T., 2006. Tokyo Bay: its environmental status - past, present, and future. In: Wolanski, E. (ed)., The Environment in Asia Pacific Harbours. Springer, Dordrecht, pp. 15-34.

Guest, M.A., Connolly, R.M., Loneragan, N.R.F., 2004. Carbon movement and assimilation by invertebrates in estuarine habitats at a scale of metres. Marine Ecology Progress Series 287, 27-34.

Hamilton, S.K., Sippel, S.J., Bunn, S.E., 2005. Separation of algae from detritus for stable isotope or ecological stoichiometry studies using density fractionation in colloidal silica. Limnology and Oceanography: Methods 3, 149-157.

Heip, C.H.R., Goosen, N.K., Herman, P.M.J., Kromkamp, J., Middelburg, J.J., Soetaert, K., 1995. Production and consumption of biological particles in temperate tidal estuaries. Oceanography and Marine Biology: An Annual Review 33, 1-149.

Hughes R.G., Paramor, O.A.L., 2004. On the loss of saltmarshes in south-east England and methods for their restoration. Journal of Applied Ecology 41, 440-448 
Jacob, U., Mintenbeck, K., Brey, T., Knust, R., Beyer, K., 2005. Stable isotope food web studies: a case for standardized sample treatment. Marine Ecology Progress Series 287, 251-253.

Kamatani, A., 1993. Changes of shore-line environments. In: Ogura, N. (ed)., Tokyo Bay: its Environmental Changes. Koseisha-Koseikaku, Tokyo, pp. 20-27. (in Japanese)

Kanaya, G., Takagi, S., Nobata, E., Kikuchi, E., 2007. Spatial dietary shift of macrozoobenthos in a brackish lagoon revealed by carbon and nitrogen stable isotope ratios. Marine Ecology Progress Series 345, 117-127.

Kang, C.K., Sauriau, P.G., Richard, P., Blanchard, G.F., 1999. Food sources of the infaunal suspension-feeding bivalve Cerastoderma edule in a muddy sandflat of Marennes-Oleron Bay, as determined by analyses of carbon and nitrogen stable isotopes. Marine Ecology Progress Series 187, 147-158.

Kang, C.K., Kim, J.B., Lee, K.S., Kim, J.B., Lee, P.Y., Hong, J.S., 2003. Trophic importance of benthic microalgae to macrozoobenthos in coastal bay systems in Korea: dual stable C and N isotope analyses. Marine Ecology Progress Series 259, 79-92.

Kennish, M.J., 2004. Coastal salt marsh systems in the U. S.: a review of anthropogenic impacts. Journal of Coastal Research 17, 731-748.

Kikuchi, E., Wada, E., 1996. Carbon and nitrogen stable isotope ratios of deposit-feeding polychaetes in the Nanakita River Estuary, Japan. Hydrobiologia 321, 69-75.

Kneer, D., Asmus, H., Vonk, J.A., 2008. Seagrass as the main food source of Neaxius 
acanthus (Thalassinidea: Strahlaxiidae), its burrow associates, and of Corallianassa coutierei (Thalassinidea: Callianassidae). Estuarine, Coastal and Shelf Science 79, 620-630

Kon, K., Kurokura, H., Hayashizaki, K., 2007. Role of microhabitats in food webs of benthic communities in a mangrove forest. Marine Ecology Progress Series 340, 55-62.

Kurata, K., Minami, H., Kikuchi, E., 2001. Stable isotope analysis of food sources for salt marsh snails. Marine Ecology Progress Series 223, 167-177.

Kwak, T.J., Zedler, J.B., 1997. Food web analysis of southern California coastal wetlands using multiple stable isotopes. Oecologia 110, 262 -277

Laegdsgaard, P., 2006. Ecology, disturbance and restoration of coastal saltmarsh in Australia: a review. Wetlands Ecology and Management 14, 379-399.

Lalli, C.M., Parsons, T.R., 1995. Biological oceanography: an introduction, second edition. Butterworth-Heineman, Oxford, 320 pp.

Li, H., Yang, S.L., 2009. Trapping effect of tidal marsh vegetation on suspended sediment, Yangtze Delta. Journal of Coastal Research 25, 915-936.

McCutchan, J.H., Lewis, W.M., Kendall, C., McGrath, C.C., 2003. Variation in trophic shift for stable isotope ratios of carbon, nitrogen, and sulfur. Oikos 102, 378-390.

Meziane, T., Sanabe, M.C., Tsuchiya, M., 2002. Role of fiddler crabs of a subtropical intertidal flat on the fate of sedimentary fatty acids. Journal of Experimental Marine Biology and Ecology 270, 191-201.

Minagawa, M., Wada, E., 1984. Stepwise enrichment of ${ }^{15} \mathrm{~N}$ along food chains: further 
evidence and the relation between $\delta^{15} \mathrm{~N}$ and animal age. Geochimica et Cosmochimica Acta 48, 1135-1140.

Nakamura, K., Tockner, K., Amano, K., 2006. River and wetland restoration: lessons from Japan. BioScience 56, 419-429.

Natuhara, Y., Kitano, M., Goto, K., Tsuchinaga, T., Imai, C., Tsuruho, K., Takada, H., 2005. Creation and adaptive management of a wild bird habitat on reclaimed land in Osaka Port. Landscape and Urban Planning 70, 283-290.

Owens, N.J.P., 1987. Natural variations in ${ }^{15} \mathrm{~N}$ in the marine environment. Advances in Marine Biology 24, 389-451.

Page, H.M., 1997. Importance of vascular plant and algal production to macro-invertebrate consumers in a southern California salt marsh. Estuarine, Coastal and Shelf Science 45, 823-834.

Paramor, O.A.L., Hughes R.G., 2004. The effects of biotrubation and harbivory by the polychaete Nereis diversicolor on loss of saltmarsh in south-east England. Journal of Applied Ecology 41, 449-463

Pethick, J., 2002. Estuarine and tidal wetland restration in the United Kingdomk: policy versus practice. Restration Ecology 10, 431-437.

Polis, G.A., Hurd, S.D., 1996. Linking marine and terrestrial food webs: Allochthonous input from the ocean supports high secondary productivity on small islands and coastal land communities. American Naturalist 147, 396-423.

Polis, G.A., Strong, D.R., 1996. Food web complexity and community dynamics. American Naturalist 147, 813-846.

Polis, G.A., Anderson, W.B., Holt, R.D., 1997. Toward an integration of landscape and 
food web ecology: the dynamics of spatially subsidized food webs. Annual Review of Ecology and Systematics 28, 289-316.

Riera, P., Stal, L.J., Nieuwenhuize, J., Richard, P., Blanchard, G., Gentil, F., 1999. Determination of food sources for benthic invertebrates in a salt marsh (Aiguillon Bay, France) by carbon and nitrogen stable isotopes: importance of locally produced sources. Marine Ecology Progress Series 187, 301-307.

Richoux, N.B., Froneman, P.W., 2007. Assessment of spatial variation in carbon utilization by benthic and pelagic invertebrates in a temperate South African estuary using stable isotope signatures. Estuarine, Coastal and Shelf Science 71, 545-558.

Sauriau, P.G., Kang, C.K., 2000. Stable isotope evidence of benthic microalgae-based growth and secondary production in the suspension feeder Cerastoderma edule (Mollusca, Bivalvia) in the Marennes-Oléron Bay. Hydrobiologia 440, 317-329.

Silliman, B.R., Bertness, M.D., 2002. A trophic cascade regulates salt marsh primary production. Proceedings of the National Academy of Sciences of USA 99, 10500-10505

Silliman, B.R., Bertness, M.D., 2004. Shoreline development drives invasion of Phragmites australis and the loss of plant diversity on New England salt marshes. Conservation Biology 18, 1424-1434

Sullivan, M.J., Moncreiff, C.A., 1990. Edaphic algae are an important component of salt marsh food-webs: evidence from multiple stable isotope analyses. Marine Ecology Progress Series 62, 149-159.

Teal, J.M., 1962. Energy flow in salt marsh ecosystem of Georgia. Ecology 43, 614-624. 
Vonk, J.A., Christianen, M.J.A., Stapel, J., 2008. Redefining the trophic importance of seagrasses for fauna in tropical Indo-Pacific meadows. Estuarine, Coastal and Shelf Science 79, 653-660.

Wainright, S.C., Weinstein, M.P., Able, K.W., Currin, C.A., 2000. Relative importance of benthic microalgae, phytoplankton and the detritus of smooth cordgrass Spartina alterniflora and the common reed Phragmites australis to brackish-marsh food webs. Marine Ecology Progress Series 200, 77-91.

Wolters, M., Garbutt b, A., Bakker, J.P., 2005. Salt-marsh restoration: evaluating the success of de-embankments in north-west Europe. Biological Conservation 123, $249-268$ 


\section{Figure captions}

Fig. 1. Tama River estuary and Obitsu River estuary study sites in Tokyo Bay, central Japan. Dark shaded and dotted areas indicate salt marsh and mudflat, respectively.

Fig. 2. Carbon $\left(\delta^{13} \mathrm{C}\right)$ and nitrogen $\left(\delta^{15} \mathrm{~N}\right)$ stable isotope plots of benthic invertebrates, sedimentary organic matter (SOM), particulate organic matter (POM), and primary producers in the (a) Tama River and (b) Obitsu River estuaries, Tokyo Bay. Error bars indicate standard deviation. Numbers and letters represent the species as follows: 1 , Helice tridens; 2, Holometopus dehaani; 3, Hemigrapsus takanoi; 4, Macrophthalmus japonicus; 5, Ilyoplax pusilla; 6, Scopimera globosa; 7, Philyra pisum; 8, Macrobrachium nipponense; 9, Palaemon macrodactylus; 10, Athanas japonicus; 11, Pagurus minites; 12, Diogenes nitidimanus; 13, Laomedia astacina; 14, Callianassa japonica; 15, Amphibalanus amphitrite; 16, Balanus albicostatus; 17, Gammaridea spp.; 18, Assiminea japonica; 19, Angustassiminea castanea; 20, Batillaria cumingii; 21, Cerithidea rhizophorarum; 22, Umbonium moniliferum; 23, Xenostrobus securis; 24, Musculista senhousia; 25, Felaniella sowerbyi; 26, Laternula marilina; 27, Ruditapes philippinarum; 28, Corbicula japonica; 29, Hediste spp.; 30, Reticunassa festiva; 31, Thais clavigera; 32, Glycera chirori; 33, Haliplanella lineata; V, vegetated habitat; U, Unvegetated habitat; F, flood tide; E, ebb tide; a, Common reed (Phragmites austrails); b, phytoplankton; c, microphytobenthos; d, drift macroalgae. 

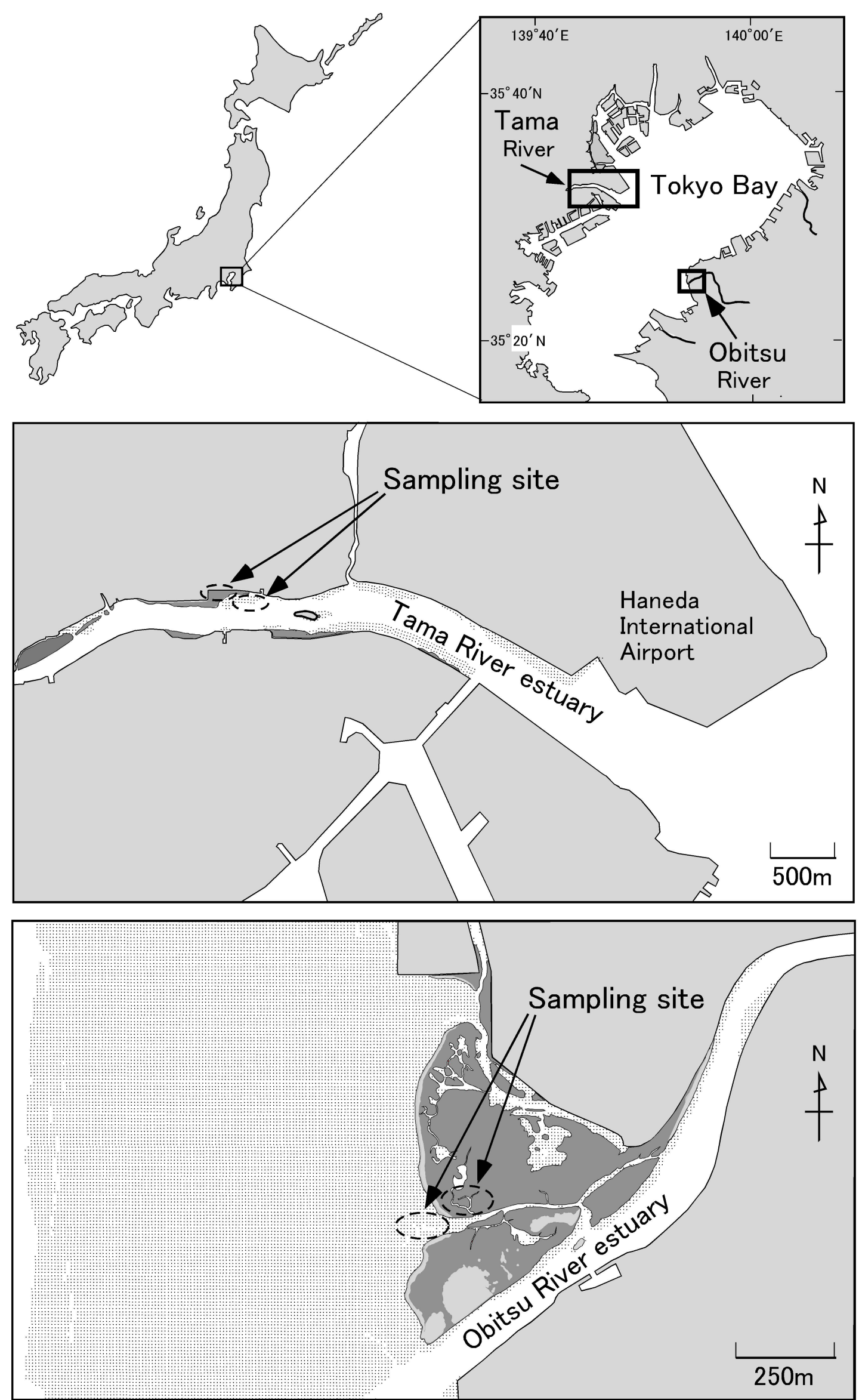

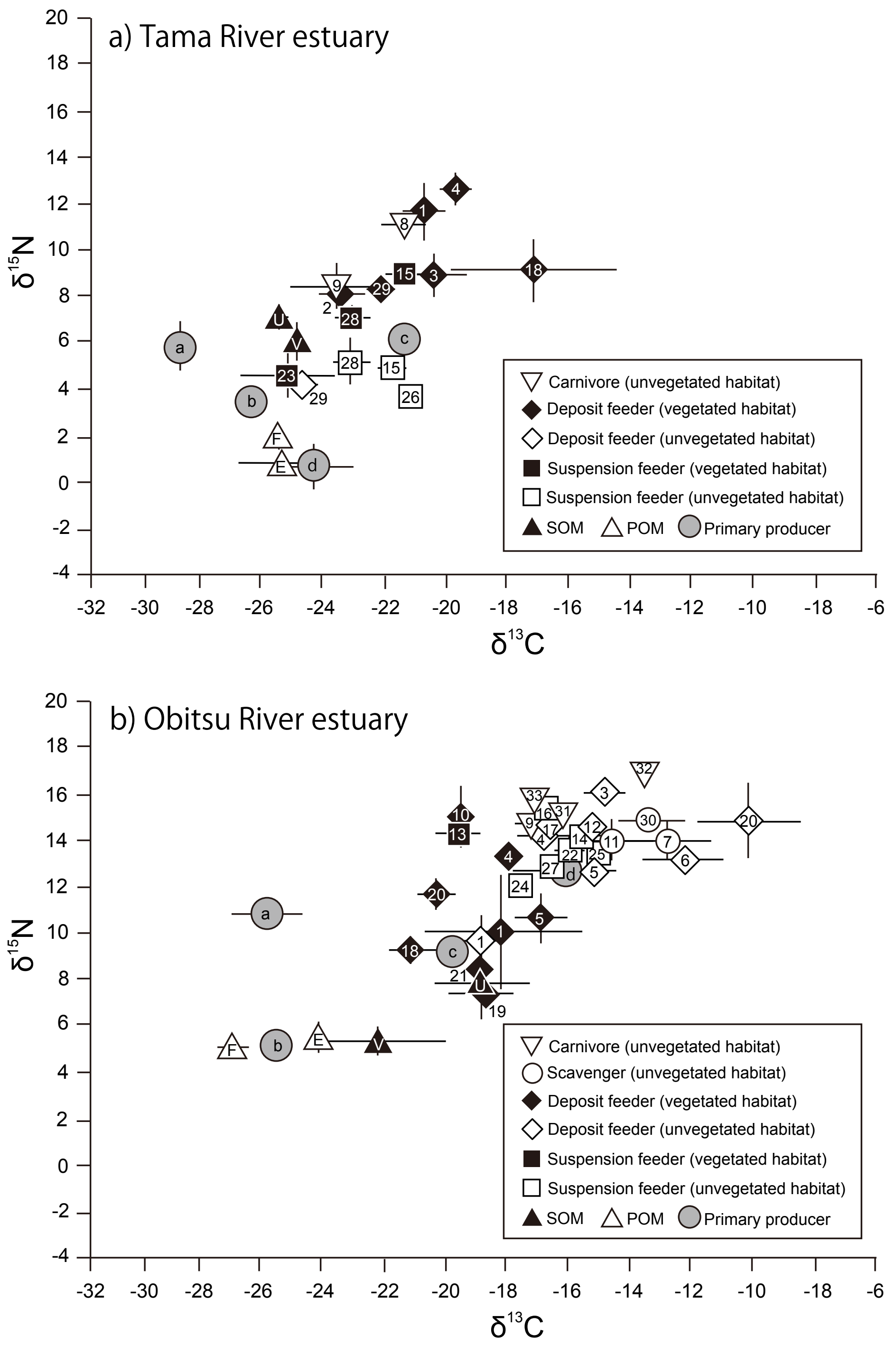
Table 1

Mean contributions (\% followed by ranges in brackets) of each potential food source or organic origin for benthic invertebrates or organic matters, calculated by IsoSource model. Values are given as the mean, in percentage, with the ranges given in parenthesis. '*' indicates suspension feeder, and another is deposit feeder. 'a' indicates sessile invertebrates, and another is mobile invertebrates. Italic indicates the highest contribution source or origin, and bold indicates exceeded 20 percent contribution source or origin.

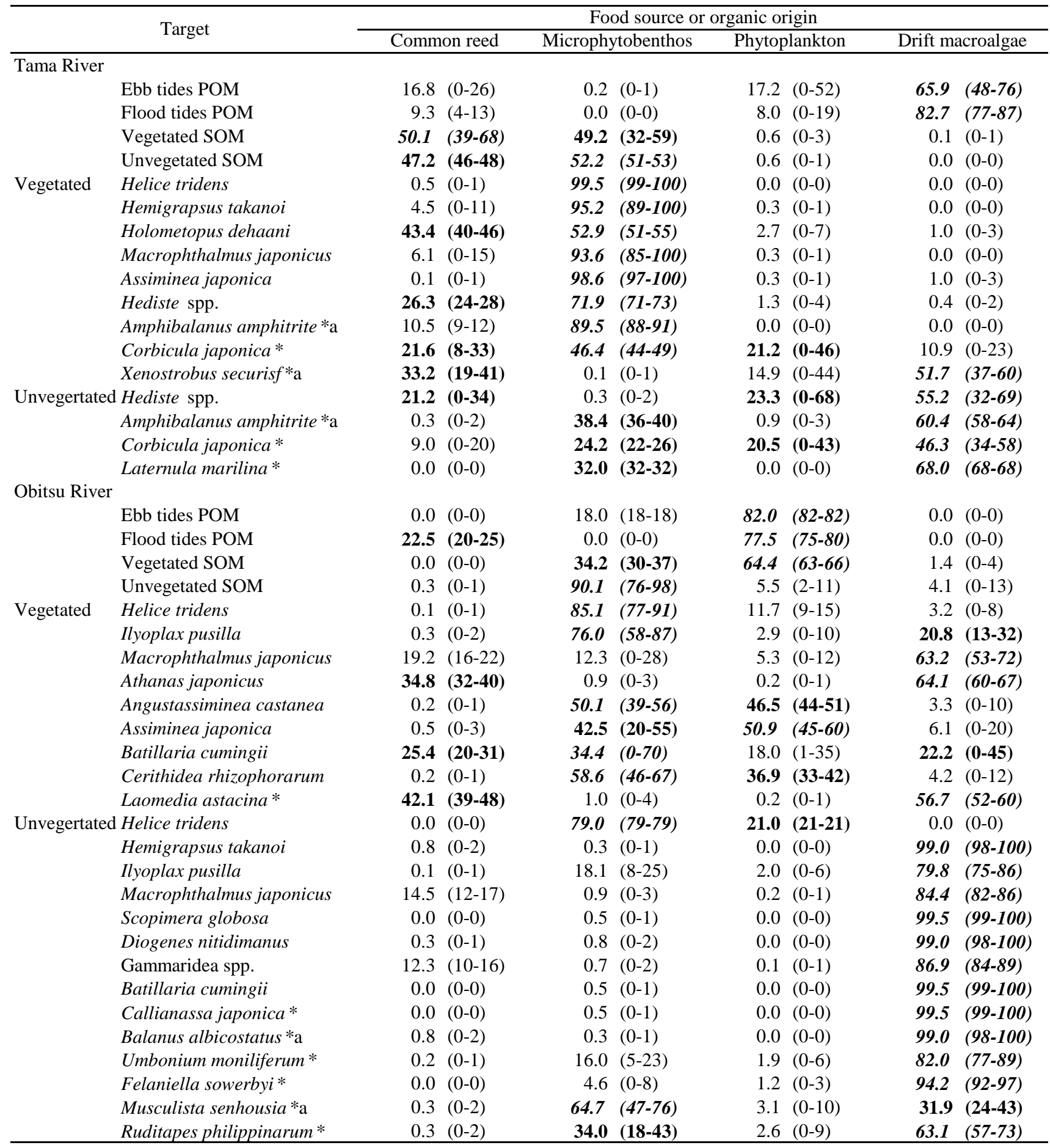


Appendix 1

Stable isotope ratios of benthic invertebrates, organic matters, and primary producers at each habitat in Tama river and Obitsu River estuary, Tokyo Bay, Japan.

\begin{tabular}{|c|c|c|c|c|c|c|c|}
\hline & Species & feeding habits & $\delta^{13} \mathrm{C}$ & Std & $\delta^{15} \mathrm{~N}$ & Std & $\mathrm{n}$ \\
\hline \multicolumn{8}{|l|}{ Tama River } \\
\hline \multicolumn{8}{|l|}{ Vegetated } \\
\hline & Helice tridens & Deposit feeder & -20.9 & 0.7 & 11.7 & 1.2 & 4 \\
\hline & Holometopus dehaani & Deposit feeder & -23.7 & 0.8 & 8.2 & 0.6 & 4 \\
\hline & Hemigrapsus takanoi & Deposit feeder & -20.5 & 1.0 & 9.0 & 0.9 & 4 \\
\hline & Macrophthalmus japonicus & Deposit feeder & -19.9 & 0.3 & 12.7 & 0.7 & 4 \\
\hline & Amphibalanus amphitrite & Suspension feeder & -21.5 & 0.1 & 9.0 & 0.1 & 4 \\
\hline & Assiminea japonica & Deposit feeder & -17.2 & 2.8 & 9.2 & 1.3 & 4 \\
\hline & Xenostrobus securis & Suspension feeder & -25.4 & 0.6 & 4.7 & 0.7 & 4 \\
\hline & Corbicula japonica & Suspension feeder & -23.3 & 0.3 & 7.2 & 0.1 & 4 \\
\hline & Hediste spp. & Deposit feeder & -22.3 & 0.4 & 8.4 & 0.5 & 4 \\
\hline \multicolumn{8}{|l|}{ Unvegetated } \\
\hline & Macrobrachium nipponense & Carnivore & -21.6 & 0.7 & 11.2 & 0.3 & 4 \\
\hline & Palaemon macrodactylus & Carnivore & -23.9 & 1.6 & 8.5 & 1.0 & 4 \\
\hline & Amphibalanus amphitrite & Suspension feeder & -22.0 & 0.5 & 5.0 & 0.3 & 4 \\
\hline & Laternula marilina & Suspension feeder & -21.3 & 0.2 & 3.7 & 0.1 & 4 \\
\hline & Corbicula japonica & Suspension feeder & -23.4 & 0.6 & 5.3 & 1.0 & 4 \\
\hline & Hediste spp. & Deposit feeder & -25.1 & 0.6 & 4.3 & 0.5 & 4 \\
\hline \multicolumn{8}{|c|}{ Organic matter } \\
\hline & Ebb tides POM & - & -25.7 & 0.0 & 2.0 & 0.4 & 3 \\
\hline & Flood tides POM & - & -25.7 & 1.5 & 0.9 & 0.1 & 3 \\
\hline & Vegetated SOM & - & -25.7 & 0.2 & 7.2 & 0.5 & 3 \\
\hline & Unvegetated SOM & - & -25.1 & 0.1 & 6.2 & 0.8 & 3 \\
\hline \multicolumn{8}{|c|}{ Primary producer } \\
\hline & Common reed & - & -29.1 & 0.4 & 6.0 & 1.1 & 3 \\
\hline & Microphytobenthos & - & -21.5 & 0.3 & 6.3 & 0.7 & 3 \\
\hline & Phytoplankton & - & -26.6 & & 3.4 & & 1 \\
\hline & Drift macroalgae & - & -24.6 & 1.3 & 0.7 & 1.4 & 4 \\
\hline \multirow{2}{*}{\multicolumn{8}{|c|}{$\begin{array}{l}\text { Obitsu River } \\
\text { Vegetated }\end{array}$}} \\
\hline & & & & & & & \\
\hline & Helice tridens & Deposit feeder & -18.2 & 2.6 & 10.1 & 2.5 & 4 \\
\hline & Ilyoplax pusilla & Deposit feeder & -16.9 & 0.9 & 10.7 & 1.1 & 4 \\
\hline & Macrophthalmus japonicus & Deposit feeder & -18.0 & 0.1 & 13.4 & 0.4 & 3 \\
\hline & Athanas japonicus & Deposit feeder & -19.5 & 0.1 & 15.0 & 1.3 & 3 \\
\hline & Laomedia astacina & Suspension feeder & -19.6 & 0.7 & 14.3 & 0.3 & 3 \\
\hline & Angustassiminea castanea & Deposit feeder & -18.9 & 1.1 & 7.4 & 0.9 & 4 \\
\hline & Assiminea japonica & Deposit feeder & -21.1 & 0.7 & 9.3 & 0.6 & 4 \\
\hline & Batillaria cumingii & Deposit feeder & -20.3 & 0.6 & 11.7 & 0.7 & 4 \\
\hline & Cerithidea rhizophorarum & Deposit feeder & -18.8 & 0.2 & 8.3 & 1.6 & 4 \\
\hline \multicolumn{8}{|l|}{ Unvegetated } \\
\hline & Helice tridens & Deposit feeder & -18.9 & 0.7 & 9.7 & 1.6 & 3 \\
\hline & Hemigrapsus takanoi & Deposit feeder & -14.8 & 0.6 & 16.1 & 0.4 & 4 \\
\hline & Ilyoplax pusilla & Deposit feeder & -15.2 & 0.3 & 12.7 & 0.6 & 4 \\
\hline & Scopimera globosa & Deposit feeder & -12.2 & 1.2 & 13.2 & 0.5 & 4 \\
\hline & Macrophthalmus japonicus & Deposit feeder & -16.8 & 0.6 & 14.3 & 0.4 & 3 \\
\hline & Philyra pisum & Scavenger & -12.8 & 1.5 & 14.0 & 0.8 & 4 \\
\hline & Palaemon macrodactylus & Deposit feeder & -16.9 & 0.5 & 14.7 & 0.4 & 4 \\
\hline & Pagurus minutus & Scavenger & -14.6 & 1.5 & 14.0 & 1.0 & 4 \\
\hline & Diogenes nitidimanus & Deposit feeder & -15.2 & 0.5 & 14.6 & 0.4 & 4 \\
\hline & Callianassa japonica & Suspension feeder & -15.3 & 0.5 & 14.3 & 0.3 & 4 \\
\hline & Balanus albicostatus & Suspension feeder & -16.6 & 0.4 & 15.5 & 0.2 & 4 \\
\hline & Gammaridea spp. & Deposit feeder & -16.6 & 0.1 & 14.4 & 0.3 & 3 \\
\hline & Batillaria cumingii & Deposit feeder & -10.1 & 1.7 & 14.8 & 1.7 & 4 \\
\hline & Umbonium moniliferum & Suspension feeder & -15.9 & 0.5 & 13.6 & 0.4 & 4 \\
\hline & Reticunassa festiva & Scavenger & -13.3 & 1.1 & 14.8 & 0.3 & 4 \\
\hline & Thais clavigera & Carnivore & -16.3 & 0.4 & 15.3 & 0.2 & 4 \\
\hline & Felaniella sowerbyi & Suspension feeder & -15.0 & 0.2 & 13.4 & 0.3 & 3 \\
\hline & Musculista senhousia & Suspension feeder & -17.5 & 0.3 & 12.0 & 0.2 & 3 \\
\hline & Ruditapes philippinarum & Suspension feeder & -16.4 & 0.1 & 12.9 & 0.2 & 4 \\
\hline & Glycera chirori & Carnivore & -13.5 & 0.1 & 16.9 & 0.3 & 4 \\
\hline & Haliplanella lineata & Carnivore & -16.9 & 0.2 & 15.6 & 0.4 & 4 \\
\hline \multicolumn{8}{|c|}{ Organic matter } \\
\hline & Ebb tides POM & - & -24.2 & 0.1 & 5.5 & 0.7 & 3 \\
\hline & Flood tides POM & - & -26.9 & 0.5 & 5.1 & 0.4 & 3 \\
\hline & Vegetated SOM & - & -22.2 & 2.1 & 5.4 & 0.7 & 3 \\
\hline & Unvegetated SOM & - & -18.8 & 1.5 & 7.9 & 1.6 & 3 \\
\hline \multicolumn{8}{|c|}{ Primary producer } \\
\hline & Reed grass & - & -25.7 & 1.1 & 10.8 & 0.4 & 3 \\
\hline & Microphytobenthos & - & -19.8 & 0.3 & 9.1 & 0.3 & 3 \\
\hline & Phytoplankton & - & -25.5 & & 5.1 & & 1 \\
\hline & Drift macroalgae & - & -16.7 & 1.6 & 12.1 & 0.9 & 18 \\
\hline
\end{tabular}

